Note

\section{Comparison of Polar Lipids in Various Parts of Variegated Tabacco Leaves}

\author{
Toshiake Matsuzaki, Akira KoIwaI \\ and Nobumaro KAWASHIMA
}

Central Research Institute, The Japan Tobacco \& Salt Public Corporation, 6-2 Umegaoka, Midori-ku, Yokohama 227, Japan

Received April 21, 1981

Polar lipids such as monogalactosyldiglyceride (MGDG), digalactosyl diglyceride (DGDG), sulfoquinovosyldiglyceride (SQDG) and phosphatidylglycerol (PG) are important constituents of chlorolast membranes. The biosynthesis of these lipids is related to the development of the membrane structures, and the biosynthetic mechanism of unsaturated fatty acids in these lipids is now under discussion, especially of the pathway for $18: 3$ between $16: 3$ and $18: 3$ plants. $^{1,2)}$ Variegated leaves of tobacco contain defective or degenerated chloroplasts in white areas of tissue as well as normal chloroplsts in green areas. ${ }^{3,4)}$ Therefore, it seems of value and helpful to compare polar lipid contents and the fatty acid compositions among various parts, with different chlorophyll contents, of the variegated leaves for the clarification of the biosynthetic mechanism. Tobacco plants (Nicotiana tabacum L. cv. Turkish Samson, variegated type $)^{3,5.6)}$ were grown in a green house at $28^{\circ} \mathrm{C}$. The 10 th to 16 th leaves on the stalk from the cotyledon were sampled from ten plants at the 10 th week after sowing. Four different parts of 10 variegated leaves, green (normal), pale green (tissue with green palisade cells and white spongy cells, or vice versa), yellow and white, collected and analyzed. The procedure for lipid analysis was as described previously. ${ }^{7}$ Briefly, crude lipids were extracted with chloroform-methanol and polar lipids were separated by two dimensional TLC. Their constituent fatty acids were analyzed by GLC and each polar lipid was estimated from the quantities of them.

Table I shows the chlorophyll contents in four different parts of variegated tobacco leaves. As expected, the chlorophyll content was highest in green tissue and next highest in pale green tissue. Yellow and white tissues had minute quantities of chlorophyll. These contents seem to reflect the amounts of chloroplasts in these tissues.

The content and fatty acid composition of each polar lipid is shown in Table II. The total amount of four chloroplastic lipids, i.e. MGDG, DGDG, SQDG and PG, was the highest in green tissue. In pale green tissue the amount was $59 \%$ of that in green tissue and the ratio was
Table I. The Contents of Chlorophyll in VARIOUS Parts OF VARIEGated TOBACCO LEAVES

\begin{tabular}{lllll}
\hline & \multicolumn{4}{c}{ Tissue } \\
\cline { 2 - 4 } & Green & $\begin{array}{c}\text { Pale } \\
\text { green }\end{array}$ & Yellow & White \\
\hline $\begin{array}{c}\text { Chlorophyll } \\
\text { Content } \\
(\mathrm{mg} / \mathrm{g} \text { dry wt) }\end{array}$ & 18.11 & 10.71 & 0.52 & 0.05 \\
$\begin{array}{c}\text { Ratio } \\
(\%)\end{array}$ & 100 & 59 & 3 & 0.3 \\
\hline
\end{tabular}

the same as that of chlorophyll content (Table I). On the contrary, yellow and white tissues had very small amounts of these four lipids (10 and $6 \%$, respectively, of green tissue). These low contents may be due to lack of chloroplasts or low ability to develop normal chloroplasts in yellow and white tissues. The content of individual chloroplastic lipids varied quite similarly among the four tissues studied. Percentage distributions of the four chloroplastic lipids (MGDG: DGDG: SQDG: PG) were $49: 34: 7: 10$ in green tissue and $49: 27: 7: 16$ in white tissue. This shows that the composition of chloroplastic lipids was very similar between green and white tissues in spite of the large difference in the amounts. It seems that overall synthesis of chloroplastic lipids is blocked in white tissue. The above results somewhat resemble the situation between etiolated and greened leaves of $A$ vena,${ }^{1}$ " where the latter have higher contents of four chloroplastic lipids than the former and the percentage composition differs little between them. Therefore, variegated tobacco leaves seem to be useful for the study of the biosynthetic mechanism of chloroplast membrane lipids.

MGDG had a considerable proportion of $16: 3$ in green tissue while in white tissue it contained only a minute amount of the acid. Also in PG the proportion of $16: 1$ was far lower in white tissue than in green tissue. The lower proportions of these unsaturated fatty acids in MGDG and PG of white tissue was replaced by the relatively higher proportion of saturated 16:0. These results suggest desaturase activity of $16: 0$ is very weak in white tissue. On the other hand, the proportion of $18: 3$ in the four chloroplastic lipids was high in both white and green tissues and showed the same level between them. This was contrary to the case of Avena where 18:3 proportions in these lipids of etiolated leaves increased considerably during greening with a concomitant derease of $18: 2$ proportions. ${ }^{1)}$ The reason why the proportion of $18: 3$ is so high in white tissue of variegated tobacco leaves is still unknown.

The contents and fatty acid compositions of other polar lipids, i.e. phosphatidylcholine (PC), phosphatidylinositol (PI), phosphatidylserine (PS) and phosphatidylethanol- 
Table II. The Contents and Fatty Acid Compositions of Polar Lipids in Various Parts of Variegated Tobacco Leaves

\begin{tabular}{|c|c|c|c|c|c|c|c|c|c|}
\hline \multirow{2}{*}{ Lipid } & \multirow{2}{*}{ Tissue } & \multirow{2}{*}{$\begin{array}{c}\text { Content } \\
\text { (mg/g dry wt) }\end{array}$} & \multicolumn{7}{|c|}{ Percent of total fatty acids $(w / w)$} \\
\hline & & & $16: 0$ & $16: 1$ & $16: 3$ & $18: 0$ & $18: 1$ & $18: 2$ & $18: 3$ \\
\hline \multirow[t]{4}{*}{ MGDG } & Green & 20.92 & 3 & & 11 & - & 1 & 3 & 82 \\
\hline & Pale green & 12.15 & 2 & & 11 & - & - & 3 & 84 \\
\hline & Yellow & 1.90 & 5 & & 1 & 1 & 1 & 3 & 89 \\
\hline & White & 1.33 & 6 & & 1 & 1 & 1 & 3 & 88 \\
\hline \multirow[t]{4}{*}{ DGDG } & Green & 14.41 & 17 & & & 2 & 1 & 4 & 76 \\
\hline & Pale green & 8.81 & 15 & & & 1 & 1 & 4 & 79 \\
\hline & Yellow & 1.31 & 15 & & & 3 & 2 & 4 & 76 \\
\hline & White & 0.73 & 17 & & & 3 & 1 & 4 & 75 \\
\hline \multirow[t]{4}{*}{ SQDG } & Green & 2.78 & 46 & & & 1 & 1 & 7 & 45 \\
\hline & Pale green & 1.46 & 48 & & & 3 & 2 & 6 & 41 \\
\hline & Yellow & 0.26 & 54 & & & 8 & 4 & 6 & 28 \\
\hline & White & 0.20 & 41 & & & 9 & 5 & 3 & 42 \\
\hline \multirow[t]{4}{*}{ PG } & Green & 4.16 & 19 & 35 & & 2 & 8 & 13 & 23 \\
\hline & Pale green & 2.66 & 23 & 34 & & 2 & 6 & 11 & 24 \\
\hline & Yellow & 0.71 & 55 & 12 & & 3 & 2 & 8 & 20 \\
\hline & While & 0.44 & 53 & 14 & & 2 & 1 & 6 & 24 \\
\hline \multirow[t]{4}{*}{ PI } & Green & 1.57 & 25 & & & 4 & 3 & 30 & 38 \\
\hline & Pale green & 1.61 & 23 & & & 4 & 2 & 30 & 41 \\
\hline & Yellow & 2.35 & 19 & & & 4 & 2 & 29 & 46 \\
\hline & White & 1.16 & 21 & & & 3 & 2 & 21 & 53 \\
\hline \multirow[t]{4}{*}{ PS } & Green & 1.10 & 40 & & & 5 & 2 & 20 & 33 \\
\hline & Pale green & 1.01 & 41 & & & 4 & 1 & 17 & 37 \\
\hline & Yellow & 0.81 & 38 & & & 4 & 1 & 15 & 42 \\
\hline & White & 0.57 & 42 & & & 6 & 1 & 11 & 40 \\
\hline \multirow[t]{4}{*}{$\mathrm{PC}$} & Green & 4.60 & 27 & & & 5 & 4 & 29 & 35 \\
\hline & Pale green & 4.11 & 29 & & & 6 & 3 & 26 & 36 \\
\hline & Yellow & 4.30 & 21 & & & 6 & 2 & 25 & 46 \\
\hline & White & 3.78 & 23 & & & 6 & 2 & 19 & 50 \\
\hline \multirow[t]{4}{*}{$\mathrm{PE}$} & Green & 2.01 & 29 & & & 4 & 2 & 37 & 28 \\
\hline & Pale green & 2.52 & 29 & & & 5 & 1 & 36 & 29 \\
\hline & Yellow & 2.38 & 27 & & & 5 & 1 & 31 & 36 \\
\hline & White & 2.53 & 27 & & & 4 & 1 & 24 & 44 \\
\hline
\end{tabular}

amine (PE), differed relatively little among four different parts of the variegated leaves. In general these polar lipids are mainly located in cellular organella other than chloroplasts. ${ }^{8)}$ Therefore, non-chloroplastic organella seem not so degenerated as chloroplasts in white tissue of variegated tobacco leaves.

\section{REFERENCES}

1) J. Ohnishi and M. Yamada, Plant \& Cell Physiol., 21, 1595 (1980).

2) P. G. Roughan, J. B. Mudd and T. T. McManus,
Biochem. J., 188, 17 (1979).

3) L. G. Burk, R. N. Stewart and H. Derman, Amer. $J$. Bot., 51, 713 (1964).

4) D. V. Wettstein and G. Eriksson, Genetics Today, 3, 591 (1965).

5) S. G. Wildman, C. Lu-Liao and F. Wong-Staal, Planta (Berl.), 113, 293 (1973).

6) S. Imaizumi and Y. Wda, Bull. Hatano Tobacco Exp. Sta., 69, 45 (1971).

7) A. Koiwai and T. Kisaki, Agric. Biol. Chem., 43, 597 (1979).

8) M. Kates, Adv. Lipid Res., 8, 225 (1970). 